\title{
Effect of Dates of Sowing on Incidence of Leaf Hoppers, Empoasca flavescens Fab. on Castor Genotypes
}

\author{
G. Laxman" and T. Uma Maheswari \\ Department of entomology, College of Agriculture, Rajendranagar (ANGRAU), \\ Hyderabad-500030, Telangana, India \\ *Corresponding author
}

\section{A B S T R A C T}

Keywords

Leafhoppers,

Empoasca flavescens,

Castor, Incidence,

Genotypes.

Article Info

Accepted:

07 September 2017

Available Online:

10 November 2017
Effect of dates of sowing on incidence leafhopper, Empoasca flavescens on castor genotypes during Kharif season 2013 revealed that incidence of leaf hoppers in general comparatively high in late sown crop than early sown crop. When castor was sown early, high hopper population was recorded on GCH-4 (98.67 hoppers) and low population on M-574 (9.00 hoppers). In the case of early sown crop, hopper burn score of 2 with 11 to 25 percent injury was observed on DPC-9, DCS-9, PCH-111, PCH-106 and Kranthi and where as in late sown crop, maximum hopper burn score of 4 with more than 50 percent hopper injury was observed on DPC-9, DCS-9, PCH288, PCH-111, RG-2835, PCH-106, PCH-222 and RG-2928.

\section{Introduction}

Castor (Ricinus communis Lin.) in an important non edible oilseed crop which is grown in arid and semi-arid regions. In India, Castor is sown during July or August and harvested around December or January. More than 20 species of insect pests were found associated with castor, but many of them were highly irregular in occurrence over years, distributed in patches with low population causing no remarkable damage to the crop. Only 10 species belonging to Lepidoptera, Hemiptera, Orthoptera and Thysanoptera showed variable economic importance and of them, five species were found regular with high degree of severity as major pests. Most of the insect pests were either defoliators or sucking pests (Sarma et al., 2005). The magnitude of insect pest problem is quite high in Southern India where castor is grown mainly as rainfed crop, resulting in lower seed yield.

The major pest problems in castor include the defoliators, semilooper, Achaea janata L., tobacco caterpillar, Spodoptera litura Fab. capsule borer, Conogethes punctiferalis Guen. and the sucking pests, leafhopper, Empoasca flavescens Fab. thrips, Retithripssyniacus Mayet and whitefly, Trialeurodes ricini Misra (DOR, 2005; Lakshminarayana and Raoof, 2005). Studies on relationship between different dates of sowing aid to find out the 
incidence of insect pests which helps to forewarn the cultivators to resort to preventive measures against such pests in time. Usually, pest occurrence and its population fluctuations depend on the changing environmental situation.

\section{Materials and Methods}

The field was ploughed thoroughly thrice to obtain fine tilth and propely levelled after removing stubbles, weeds and trash. Two sowings were taken up on 30.07.2013 and 30.08 .2013 by dibling the seed with a spacing of $90 \times 60 \mathrm{cms}$ at the rate of two seeds per hill. Gap filling was done a week after germination.

The seedlings were thinned out within 15 days after sowing allowing one healthy seedling to grow for hill. The recommended dose of fertilizer i.e., $80 \mathrm{~kg} \mathrm{~N}, 60 \mathrm{~kg} \mathrm{P}$ and 40 $\mathrm{kg} \mathrm{K} / \mathrm{ha}$ was applied, of which half dose of nitrogen and the entire dose of potash and phosphorus were applied as basal and rest of nitrogen at 30, 60 and 90 days after germination in equal doses.

The experimental plots were irrigated as and when required. Pre-emergence herbicide Pendimethalin 30 EC was applied a day after sowing to arrest the growth of weeds. Hand weeding was done twice so as to keep the crop free of weeds. Leaf hoppers counts including both nymph and adults were recorded on three leaves in each plant selecting one leaf from top (excluding two top most leaves), middle (medium maturity) and bottom (leaving 1 or 2 bottom most leaves) on the main shoot. Population was recorded as no of leaf hoppers/3 leaves/plant and percent leaf area burnt per plant (average of three plants). Observations were taken in the early morning (6.00-8.00am) hours and leaf hoppers count will be recorded and percent of leaf burnt (hopper burn) at peak infestation was reported. Hopper burn injury was recorded by following the score index given by Directorate of Oilseeds Research, Rajendranagar, Hyderabad.

Score index (0-4 score):

0 - No injury

1- Hopper burnt upto $10 \%$

2- Hopper burnt $11-25 \%$

3- Hopper burnt 26-50\%

4- Hopper burnt above 50\%

\section{Results and Discussion}

Effect of early sowing on incidence of leafhoppers, Empoasca flavescens on castor genotypes

Study on effect of dates of sowing on incidence of leafhoppers, Empoasca flavescens on castor genotypes revealed that when genotypes were sown early during the month of July, the genotype GCH-4 has recorded maximum hopper population of 98.67 where genotype, $\mathrm{PCH}-254$ has recorded minimum of 9.00 hoppers per plant and average of 2 score hopper burn with 11 to 25 percent hopper burn injury. However, when the castor crop is sown early, only hopper burn to an extent 25 percent with maximum of 2 score was reported in majority of the genotypes i.e. DPC-9 with 80.33 hoppers, DCS-9 with 88.33 hoppers, PCH-111 with 87.67 hoppers and Kranthi with 89.67 hoppers. Similarly the genotypes, $\mathrm{PCH}-288$ with 80.33 hoppers, RG-2835 with 83.00 hoppers, RG-1180 with 52.33 hoppers and RG-776 with 77.00 hoppers.

When the genotypes was sown early, the genotypes 48-1, Haritha. PCH-254, M-574, PCH-248, PCH-294, PCH-262 and PCH-282 though few hopper population ranging from 10.00 to 22.00 was recorded with no hopper burn symptom (Table 1). 
Table.1 Incidence of leafhoppers, Empoasca flavescens on early sown crop

\begin{tabular}{|c|c|c|c|c|c|c|c|c|}
\hline Genotypes & $\begin{array}{l}\text { Hoppers/3 } \\
\text { leaves/plant }\end{array}$ & $\begin{array}{c}\text { Hopper } \\
\text { burn/plant }\end{array}$ & $\begin{array}{l}\text { Hoppers/3 } \\
\text { leaves/plant }\end{array}$ & $\begin{array}{c}\text { Hopper } \\
\text { burn/plant }\end{array}$ & $\begin{array}{c}\text { Hoppers/3 } \\
\text { leaves/plant }\end{array}$ & $\begin{array}{c}\text { Hopper } \\
\text { burn/plant }\end{array}$ & $\begin{array}{c}\text { Mean } \\
\text { hoppers/ } 3 \\
\text { leaves/3plants }\end{array}$ & $\begin{array}{c}\text { Mean hopper } \\
\text { burn/plant }\end{array}$ \\
\hline DPC-9 & 91 & 2 & 83 & 2 & 67 & 2 & $80.33(4.39)$ & 2 \\
\hline DCS-9 & 87 & 2 & 69 & 1 & 71 & 2 & $75.67(4.33)$ & 2 \\
\hline $48-1$ & 10 & 0 & 5 & 0 & 15 & 0 & $10.00(2.32)$ & 0 \\
\hline Haritha & 27 & 0 & 15 & 0 & 18 & 0 & $20.00(3.02)$ & 0 \\
\hline PCH-288 & 93 & 2 & 71 & 1 & 77 & 1 & $80.33(4.39)$ & 1 \\
\hline PCH-111 & 77 & 2 & 99 & 2 & 87 & 2 & $87.67(4.48)$ & 2 \\
\hline PCH-254 & 10 & 0 & 15 & 0 & 10 & 0 & $11.67(2.52)$ & 0 \\
\hline M-574 & 10 & 0 & 8 & 0 & 9 & 0 & $9.00(2.30)$ & 0 \\
\hline Kiran & 99 & 3 & 79 & 1 & 87 & 2 & $88.33(4.49)$ & 2 \\
\hline PCH-248 & 24 & 0 & 25 & 0 & 17 & 0 & $22.00(3.12)$ & 0 \\
\hline PCH-294 & 45 & 0 & 39 & 0 & 57 & 0 & $47.00(3.86)$ & 0 \\
\hline PCH-262 & 15 & 0 & 25 & 0 & 19 & 0 & $19.67(3.01)$ & 0 \\
\hline GCH-4 & 100 & 2 & 99 & 2 & 97 & 2 & $98.67(4.60)$ & 2 \\
\hline PCH-282 & 20 & 0 & 31 & 0 & 19 & 0 & $23.33(3.17)$ & 0 \\
\hline RG-2835 & 63 & 1 & 75 & 1 & 89 & 2 & $75.67(4.33)$ & 1 \\
\hline PCH-106 & 88 & 2 & 91 & 3 & 65 & 1 & $81.33(4.40)$ & 2 \\
\hline PCH-222 & 77 & 1 & 93 & 2 & 79 & 1 & $83.00(4.43)$ & 1 \\
\hline RG-2928 & 91 & 2 & 77 & 1 & 81 & 1 & $83.00(4.43)$ & 1 \\
\hline RG-1180 & 53 & 0 & 41 & 0 & 63 & 2 & $52.33(3.96)$ & 1 \\
\hline RG-776 & 77 & 1 & 67 & 1 & 87 & 1 & $77.00(4.35)$ & 1 \\
\hline Kranthi & 93 & 2 & 89 & 2 & 87 & 2 & $89.67(4.51)$ & 2 \\
\hline SEm & & & & & & & 0.16 & \\
\hline $\begin{array}{l}\mathrm{CD} \\
(\mathrm{P}=0.05)\end{array}$ & & & & & & & 0.33 & \\
\hline
\end{tabular}

Figures in parenthesis are logarithmic transformed values.

SED $=$ Standard error of difference

$\mathrm{CD}(\mathrm{P}=0.05)=$ Critical Difference at $5 \%$ level of significance 
Table.2 Incidence of leafhoppers, Empoasca flavescens on late sown crop

\begin{tabular}{|c|c|c|c|c|c|c|c|c|}
\hline Genotypes & $\begin{array}{c}\text { Hoppers/3 } \\
\text { leaves/plant }\end{array}$ & $\begin{array}{l}\text { Hopper } \\
\text { burn/plant }\end{array}$ & $\begin{array}{l}\text { Hoppers/3 } \\
\text { leaves/plant }\end{array}$ & $\begin{array}{c}\text { Hopper } \\
\text { burn/plant }\end{array}$ & $\begin{array}{c}\text { Hoppers/3 } \\
\text { leaves/plant }\end{array}$ & $\begin{array}{c}\text { Hopper } \\
\text { burn/plant }\end{array}$ & $\begin{array}{l}\text { Mean hoppers/ } \\
3 \text { leaves/3plant }\end{array}$ & $\begin{array}{c}\text { Mean } \\
\text { hopper } \\
\text { burn/plant }\end{array}$ \\
\hline DPC-9 & 198 & 4 & 185 & 4 & 127 & 4 & $170.00(5.12)$ & 4 \\
\hline DCS-9 & 175 & 4 & 172 & 4 & 156 & 3 & $167.67(5.13)$ & 3 \\
\hline $48-1$ & 25 & 0 & 13 & 0 & 13 & 0 & $17.00(2.85)$ & 0 \\
\hline Haritha & 67 & 2 & 81 & 2 & 78 & 2 & $75.33(4.33)$ & 2 \\
\hline PCH-288 & 251 & 4 & 189 & 4 & 355 & 4 & $265.00(5.55)$ & 4 \\
\hline PCH-111 & 220 & 4 & 310 & 4 & 245 & 4 & $258.33(5.55)$ & 4 \\
\hline PCH-254 & 20 & 0 & 24 & 0 & 21 & 0 & $21.67(3.12)$ & 0 \\
\hline M-574 & 17 & 0 & 22 & 0 & 14 & 0 & $17.67(2.91)$ & 0 \\
\hline Kiran & 212 & 3 & 225 & 3 & 200 & 3 & $212.33(5.36)$ & 3 \\
\hline PCH-248 & 24 & 1 & 23 & 1 & 35 & 1 & $27.33(3.33)$ & 1 \\
\hline PCH-294 & 87 & 2 & 73 & 2 & 75 & 2 & $78.33(4.371)$ & 2 \\
\hline PCH-262 & 25 & 0 & 40 & 0 & 22 & 0 & $29.00(3.37)$ & 0 \\
\hline GCH-4 & 315 & 3 & 300 & 3 & 305 & 3 & $306.67(5.73)$ & 3 \\
\hline PCH-282 & 44 & 1 & 51 & 2 & 49 & 0 & $48.00(3.89)$ & 1 \\
\hline RG-2835 & 233 & 4 & 230 & 4 & 164 & 4 & $209.00(5.34)$ & 4 \\
\hline PCH-106 & 240 & 4 & 194 & 4 & 224 & 4 & $219.33(5.39)$ & 4 \\
\hline PCH-222 & 266 & 4 & 263 & 4 & 261 & 4 & $263.33(5.58)$ & 4 \\
\hline RG-2928 & 218 & 4 & 119 & 4 & 202 & 4 & $179.67(5.16)$ & 4 \\
\hline RG-1180 & 78 & 2 & 74 & 2 & 88 & 2 & $80.00(4.39)$ & 2 \\
\hline RG-776 & 112 & 3 & 134 & 3 & 120 & 3 & $122.00(4.81)$ & 3 \\
\hline Kranthi & 260 & 3 & 190 & 3 & 150 & 3 & $200.00(5.28)$ & 3 \\
\hline SEm & & & & & & & 0.16 & \\
\hline $\mathrm{CD}(\mathrm{P}=0.05)$ & & & & & & & 0.322 & \\
\hline
\end{tabular}

Figures in parenthesis are logarithmic transformed values.

SED $=$ Standard error of difference

$\mathrm{CD}(\mathrm{P}=0.05)=$ Critical Difference at $5 \%$ level of significance 
Fig.1 Incidence of leafhoppers, Empoasca flavescens on castor genotypes in early (30.07.2013) and late (30.08.2013) sowings

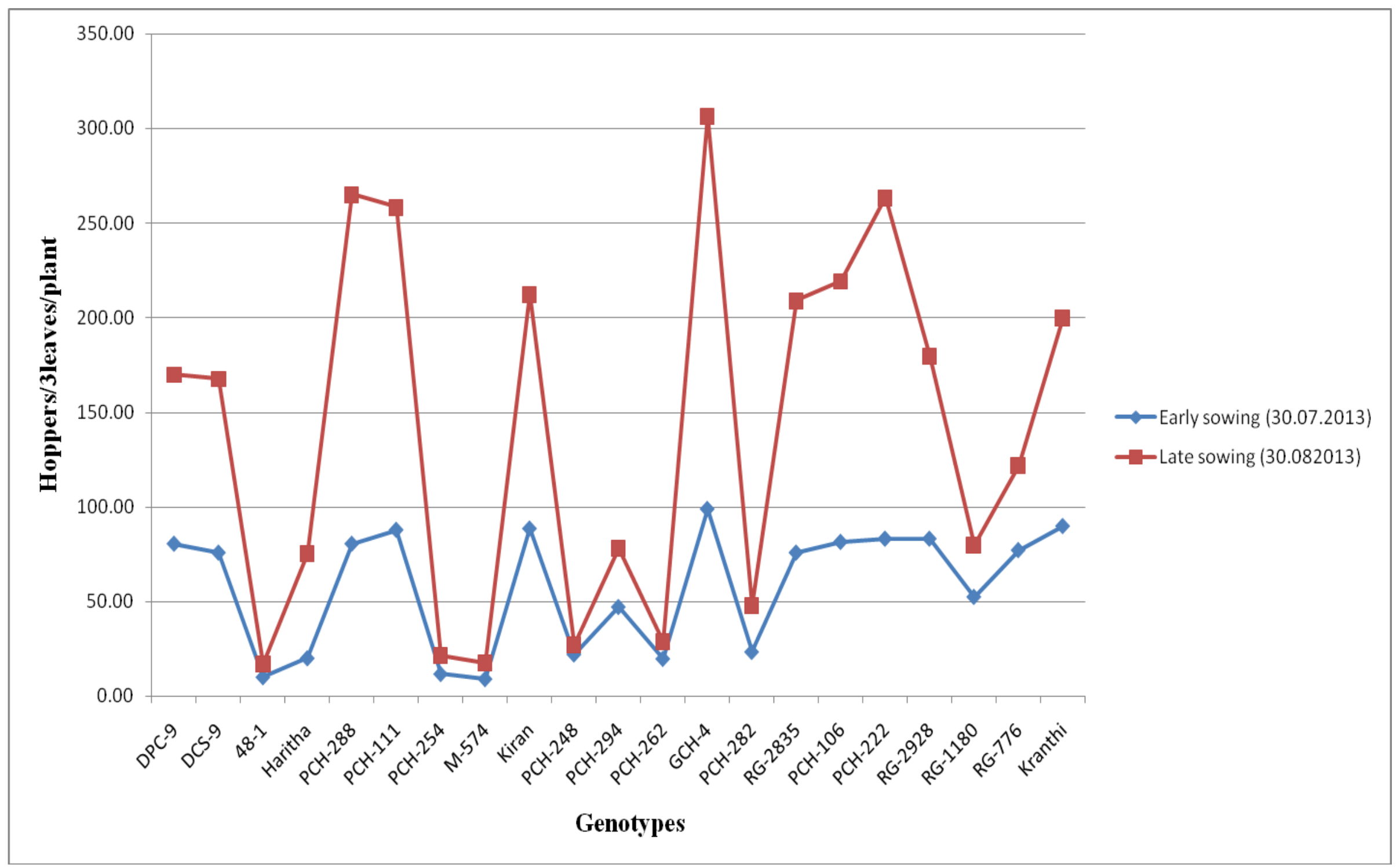


Effect of late sowing on incidence of leafhoppers, Empoasca flavescens on castor genotypes

Data presented in the table 2 revealed that when genotypes were sown late by 30 days during August, in general highest hopper burn score of 4 was observed in some genotypes like DPC-9, PCH-288, PCH-111, RG-2835, PCH-106, PCH-222 and RG-2928 showing more than 50 percent hopper burn injury. Similarly, certain genotypes including 48-1, PCH-254, M-574 and PCH-262 have exhibited hopper burn symptom though meagre population ranging from 17.00 to 29.00 was observed. The genotypes, DCS-9, Kiarn, GCH-4, RG-776 and Kranthi have recorded hopper burn score of 3 with 167.67, 212.33, 306.67, 122.00 and 200.00 hoppers per plant. Hopper burn ranging from 11 to 25 percent recording 2 score hopper burn was observed in the genotypes, Haritha (75.33 hoppers), PCH-294 (78.33 hopper) and RG1180 (80.00 hoppers). Hopper burn score of 1 with 1 to 10 percent was observed in the genotypes $\mathrm{PCH}-248$ and $\mathrm{PCH}-282$ with less than 50.00 hoppers per plant.

Overall comparison of incidence of major sucking pest leafhopper, $E$. flavescens between early and late sowing with an interval of 30 days during July and August, 2013. It was clear that the late sown crop was much preferred, indicated by the enormous increase in population to a maximum of 306.67 hoppers as in the case of $\mathrm{GCH}-4$, 265.00 in case of PCH-288, PCH-222 and 258.33 in the case of PCH-111. Similarly, maximum of 4 score with more than 50.00 percent hopper burn was recorded in the case of genotypes, DPC-9, PCH-288, PCH-111, RG-2835, PCH-106 and RG-2928. The genotypes DCS-9, Kiran, GCH-4, RG-776 and kranthi showing a score of 3 with 26.00 to 50.00 percent hopper burn recorded an average population ranging from 122.00 to
306.67 hoppers per three leaves per plant. A score of 2 showing 11.00 to 25.00 percent hopper burn was observed in the genotypes, Haritha and PCH-262, in the late sown crop which was completely free from infestation when sown early during the month of July. The outstanding contribution from the present study is that the genotypes, 48-1, PCH-254 and M-574 remained totally free from leafhopper infestation even if sown early. But certain genotypes including $\mathrm{PCH}-294$ and $\mathrm{PCH}-282$ which were free of hopper infestation during early sowing became susceptible to hopper infestation recording hopper burn of 1.00 to 10.00 percent with the score of 1 indicating their variation in the degree of infestation which might be based on leaf characters. In contrast, drastically change in hopper burn score from 1 to 4 was observed indicating genotype, susceptibility to hopper as seen in the case of genotypes, PCH-288, RG-2835, PCH-222 and RG-2928 when sown late. This might be due to multiplication of the pest which is enhanced by cold and humid weather i.e. temperature ranging from a maximum of $28.7^{\circ} \mathrm{C}$ and minimum of $14.62^{\circ} \mathrm{C}$ as well as relative humidity ranging from $50.00 \%$ to $86.00 \%$ during November might have favoured the hopper incidence. Present results confirm the observations made by Akashe et al., (2015), Jayaraj and Basheer (1964), Jayraj (1966) and APR castor (1986).

\section{References}

Akashe, V. B., Indi, D. V., Patil, S. R., Jadhav, J. D. and Pawar, P. B. 2015. Incidence of insect pest damage in castor in relation to meteorological parameters in the scarcity zone of Maharashtra. Journal of Agrometeorology, 17 (1): 139-141.

Annual progress report on castor. 1986. Annual castor research workers group meeting at directorate of oilseeds 
research, Hyderabad-500 030.

DOR, 2005. Integrated Pest Management in Oilseed Crops. 2nd revised edition, Directorate of Oilseeds Research, Hyderabad.

Jayaraj, S., 1966. Influence of sowing times of castor varieties on their resistance to the leafhopper, Empoasca flavescens (homoptera, jassidae). Entomological Experimental Application. 9: 359-369.

Jayaraj, S., and Basheer, M. 1964. Biological observations on the castor leaf - hopper,
Empoasca flavescens (F) (Jassidae: Homoptera). Madras Agricultural Journal. 51: 89-90.

Lakshminarayana, M., and Raoof, M. A. 2005. Insect pests and diseases of castor and their management. Directorate of Oilseeds Research. 78.

Sarma, A. K., Singh, M. P and Singh, K. I. 2005. Studies on insect-pests of castor in the agro-ecosystem of Manipur. Journal of Applied Zoological Researches. 16(2): 164-165.

\section{How to cite this article:}

Laxman, G. and Uma Maheswari, T. 2017. Effect of Dates of Sowing on Incidence of Leaf Hoppers, Empoasca flavescens Fab. on Castor Genotypes. Int.J.Curr.Microbiol.App.Sci. 6(11): 431-437. doi: https://doi.org/10.20546/ijcmas.2017.611.050 